\title{
Reduction of beta cell mass: partial insulin secretory compensation from the residual beta cell population in the nicotinamide-streptozotocin Göttingen minipig after oral glucose in vivo and in the perfused pancreas
}

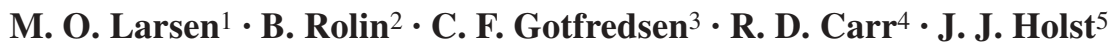 \\ ${ }^{1}$ Department of Pharmacology Research 1, Pharmacology, Research and Development, Novo Nordisk Park, Måløv, Denmark \\ ${ }^{2}$ Department of Pharmacology Research 3, Novo Nordisk, Måløv, Denmark \\ ${ }^{3}$ Department of Pharmacology Research 4, Novo Nordisk, Måløv, Denmark \\ ${ }^{4}$ Discovery Management, Novo Nordisk, Bagsværd, Denmark \\ ${ }^{5}$ Department of Medical Physiology, Panum Institute, University of Copenhagen, Denmark
}

\section{Abstract}

Aims/hypothesis. A progressive loss of beta cell function and mass are important contributory factors in the development and progression of type 2 diabetes. The aim of this study was to evaluate the effects of a primary reduction in beta cell mass on beta cell function in vivo and in the perfused pancreas and to relate these characteristics to beta cell mass.

Methods. The beta cell mass of six Göttingen minipigs was reduced chemically (using $67 \mathrm{mg} / \mathrm{kg}$ nicotinamide and $125 \mathrm{mg} / \mathrm{kg}$ streptozotocin). Six untreated minipigs were kept as control animals. Insulin responses were evaluated in vivo using the mixed meal tolerance test ( $2 \mathrm{~g} / \mathrm{kg}$ oral glucose) and in the isolated perfused pancreata from the same animals by stimulation with glucose, glucagon-like peptide- 1 or arginine.

Results. Beta cell mass was reduced in the beta-cellreduced animals compared with the control minipigs $(182 \pm 76$ vs $464 \pm 156 \mathrm{mg}, p<0.01)$. AUC $\mathrm{glucose}$ was increased in the beta-cell-reduced animals $(1383 \pm 385$ vs
$853 \pm 113 \mathrm{mmol} \cdot \mathrm{l}^{-1} \cdot \mathrm{min}$ in control minipigs, $p<0.01$ ), as was the insulin response to oral glucose per unit of beta cell mass $\left(123 \pm 84\right.$ vs $56 \pm 24 \mathrm{pmol} \cdot \mathrm{l}^{-1} \cdot \mathrm{min} \cdot \mathrm{mg}^{-1}$, $p<0.05)$. Total in vitro insulin secretion was increased per unit of beta cell mass in nicotinamide + streptozotocin pancreata compared to controls $(83.7 \pm 45.9$ vs $34.6 \pm 14.4 \mathrm{nmol} / \mathrm{mg}$ beta cells, $p<0.05)$ with responses to glucose and glucagon-like peptide-1 showing a partial compensation for reduced beta cell mass, whereas no compensation was seen in response to arginine. Conclusions/interpretation. A primary reduction in beta cell mass impairs glucose tolerance and leads to a compensatory increase in insulin secretion from the remaining beta cells after oral glucose in vivo, which is even more apparent in the perfused pancreas. It remains to be determined whether this compensation can be maintained in the long term.

Keywords Arginine - Beta cell function - Beta cell mass · Glucagon-like peptide-1 - Glucose · Minipig · Perfused pancreas $\cdot$ Streptozotocin
Received: 1 April 2004 / Accepted: 12 July 2004

Published online: 24 November 2004

C) Springer-Verlag 2004

M. O. Larsen ( $\bullet)$

Department of Pharmacology Research 1,

Pharmacology, Research and Development,

Novo Nordisk Park, F6.1.30, Novo Nordisk,

2760 Måløv, Denmark

E-mail:mmla@novonordisk.com

Tel.: +45-4442-7675, Fax: +45-4442-7488

Conflict of interest statement: M.O. Larsen, B. Rolin, C.F. Gotfredsen and R.D. Carr are all employees and shareholders at Novo Nordisk. J.J. Holst has been on advisory boards for Novo Nordisk.

\section{Introduction}

The causes of disturbed beta cell function in type 2 diabetes are not known in detail, but increased insulin secretion by the individual beta cells in response to insulin resistance and/or hyperglycaemia could be an important factor in the deterioration of beta cell function $[1,2]$. Normalisation of glycaemia with insulin in type 2 diabetic patients can enhance beta cell function $[3,4,5]$, and strategies to reduce insulin secretion

Abbreviations: GLP-1, glucagon-like peptide-1 .

MMTT, mixed meal tolerance test - NIA, nicotinamide ·

STZ, streptozotocin 
Table 1. Sequence of stimulation of insulin secretion in the perfused pancreas

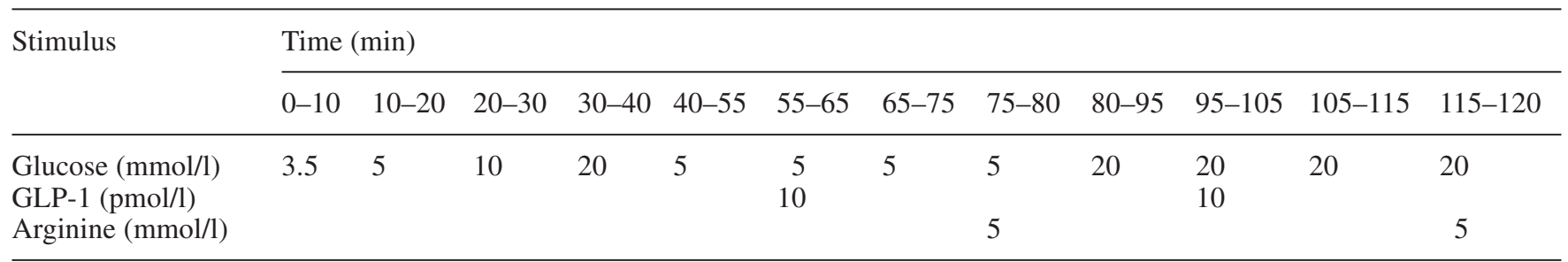

There was an equilibration period of 30 minutes at a glucose concentration of $3.5 \mathrm{mmol} / \mathrm{l}$ prior to the start of the experiment

have been shown to improve beta cell function in these patients $[6,7]$ and in rodent models of diabetes $[8,9]$.

In addition to reduced insulin action and beta cell function, a reduction in beta cell mass is also thought to be a key factor in type 2 diabetes $[10,15]$; however, the extent to which this is involved in the development of the disease remains to be determined.

Further investigations into the effects of a primary reduction in beta cell mass on beta cell function are therefore warranted. The exact amount of insulin secreted in response to specific stimuli can be difficult to quantify in vivo because several factors that influence insulin secretion and clearance (e.g. hormones, blood flow and neuronal regulation) cannot be controlled. By isolating and perfusing the pancreas, the effect of changing a single parameter can be evaluated in the intact organ.

Studies of the perfused pancreas from beta-cell-reduced rodents have indicated a dysfunction of the remaining beta cell population in hyperglycaemic animals $[16,17]$, but not in normoglycaemic animals $[16$, 18]. However, it is at present unclear how the changes observed in vitro relate to the defects in insulin secretion seen in individual beta-cell-reduced animals in vivo, and what their role in the development of diabetes might be. The nicotinamide (NIA)-streptozotocin (STZ) Göttingen minipig is a model of moderate insulin deficiency and hyperglycaemia due to a primary reduction in beta cell mass [19]. In this model, beta cell function in vivo has previously been demonstrated to be closely related to beta cell mass [20]. Furthermore, an isolated perfused pancreas preparation has been developed in this species [21, 22, 23].

The aim of the present study was to evaluate the effects of a primary reduction of beta cell mass on glucose tolerance and beta cell function in vivo and in the perfused pancreas from the same animals and to relate these characteristics to beta cell mass.

\section{Materials and methods}

Animals. Male Göttingen minipigs (aged 11-14 months, weight $26 \pm 3 \mathrm{~kg}$ [range $21-30], n=12$ ) were obtained from the barrier unit at Ellegaard Göttingen minipigs (Dalmose, Denmark) and housed in single pens under controlled conditions as described previously [19]. Pigs were allowed at least 2 weeks recovery after surgery and were trained carefully in all experimental procedures prior to the start of the experiments. Insulin secretion in response to a mixed meal tolerance test (MMTT) was evaluated in vivo in all animals. This was followed by isolation and perfusion of the pancreata and evaluation of beta cell mass. Principles of laboratory animal care were followed and the study type was approved by the Animal Experiments Inspectorate, Ministry of Justice, Denmark.

Surgical implantation of central venous catheters. Two central venous catheters (Certo 455, B. Braun Melsungen, Melsungen, Germany) were inserted surgically under general anaesthesia, and post-surgical analgesia was maintained as previously described [19]. At the start of the study period, all animals had recovered fully from the surgical procedure as evaluated by normal behaviour and eating patterns.

Beta cell mass reduction. Beta cell mass was reduced in six animals using a combination of $67 \mathrm{mg} / \mathrm{kg}$ NIA (Sigma N-3376; Sigma-Aldrich, Steinheim, Germany) and $125 \mathrm{mg} / \mathrm{kg} \mathrm{STZ}$ (Sigma S-0130; Sigma-Aldrich) as described previously [19], and six animals were kept as untreated controls.

Mixed meal tolerance test. The MMTT, consisting of $25 \mathrm{~g}$ SDS minipig fodder and $2 \mathrm{~g} / \mathrm{kg}$ glucose $(500 \mathrm{~g} / \mathrm{l}$; SAD, Copenhagen, Denmark), was performed in non-restrained animals as described previously [19]. The MMTT was performed in the beta-cell-reduced animals (NIA+STZ group) 1 week after treatment.

Perfusion of the isolated pancreas. The pancreata from all animals were isolated under general anaesthesia induced with thiomebumal and maintained with an i.v. infusion of 50-100 mg/kg chloralose (Merck, Darmstadt, Germany) and $\mathrm{N}_{2} \mathrm{O} / \mathrm{O}_{2}$ as described prevously [21, 23]. The isolated pancreata were placed in a single-pass perfusion system and perfused at a rate of $24 \mathrm{ml} / \mathrm{min}$ with a medium consisting of Krebs-Ringer bicarbonate buffer supplemented with 5\% dextran (Dextran T 70; Pharmacia, Uppsala, Sweden) [22]. After a baseline period of $30 \mathrm{~min}$ at a concentration of $3.5 \mathrm{mmol} / \mathrm{l} \mathrm{glu}-$ cose, the dose response to glucose was evaluated; responses to glucagon-like peptide-1 (GLP-1) and arginine at high and low concentrations of glucose were subsequently assessed (see Table 1 for details).

The venous effluent was collected for 1-min periods into polyethylene tubes (Minisorp, Technunc Roskilde, Denmark), chilled in ice and kept at $-20^{\circ} \mathrm{C}$ until analysis. In beta-cell-reduced animals, the perfusion was performed 3-6 weeks after the administration of NIA+STZ.

Handling and analysis of samples. Blood samples were immediately transferred to vials containing EDTA (at a final concentration of $1.6 \mathrm{mg} / \mathrm{ml}$ ) and $500 \mathrm{KIU} / \mathrm{ml}$ full blood aprotinin (10,000 KIU/ml Trasylol; Bayer, Lyngby, Denmark) and kept 
Table 2. Parameters measured during a mixed meal tolerance test in beta-cell-reduced (NIA+STZ) and control Göttingen minipigs

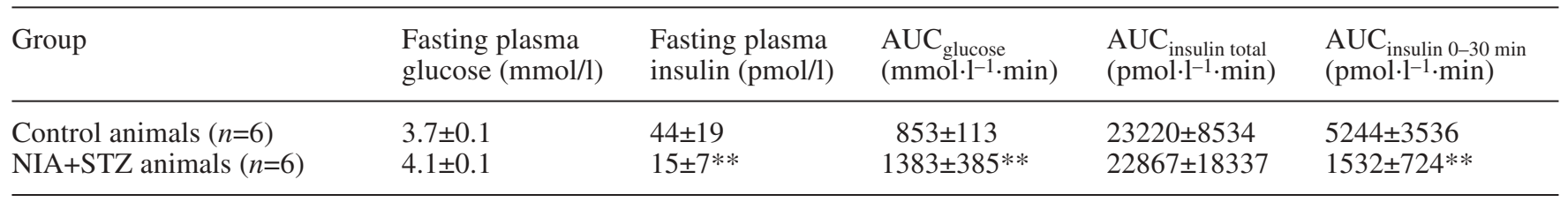

** $p<0.01$ vs control animals by the Mann-Whitney test

on ice. Samples were centrifuged $\left(1550 \mathrm{~g}\right.$ for $10 \mathrm{~min}$ at $\left.4^{\circ} \mathrm{C}\right)$, and the plasma separated and stored at $-20^{\circ} \mathrm{C}$ until analysis. Plasma glucose was analysed by the immobilised glucose oxidase method, using a $10-\mu \mathrm{l}$ aliquot of plasma in $0.5 \mathrm{ml}$ buffer (EBIO plus auto analyser and solution; Eppendorf, Hamburg, Germany). Plasma insulin was analysed using a two-site immunometric assay, with monoclonal antibodies as the catching and detecting antibodies (catching antibody, HUI-018 raised against the A-chain of human insulin; detecting antibody, OXI005 raised against the B-chain of bovine insulin) [24] as described previously [19].

All effluent fractions from the perfused pancreas were analysed for insulin by the same assay as that used to assess plasma insulin, using porcine insulin in PBS, pH 7.2 (Merck Eurolab, Copenhagen, Denmark) with 3\% (w/v) Byco C (Croda Nordica, Malmö, Sweden) for calibration. Samples were diluted 1:10 in 3\% (w/v) Byco C in PBS, pH 7.2 prior to analysis.

Histological examination of pancreas. At the end of the perfusion protocol, the pancreata were perfused with $4 \%$ paraformaldehyde (Bie and Berntsen, Copenhagen, Denmark) and kept in $4 \%$ paraformaldehyde for 24 hours before fractionation, embedding in 3\% agar solution (catalogue number 303289; Meco-Benzon, Copenhagen, Denmark), staining (primary antibody to insulin and a mixture of antibodies to glucagon, somatostatin and pancreatic polypeptide), and histological examination (stereological, using the smooth fractionator method [25, 26], as described [19]).

Evaluation of results. The area under curve (AUC) for glucose and insulin during the MMTT were calculated using the trapezoidal method, with baseline $=0$. The insulin response to stimulation during pancreas perfusion was calculated as total secretion. Results were evaluated using the Mann-Whitney test or repeated measures two-way ANOVA, with data logarithmically transformed to establish stability of variance. A $p$ value of 0.05 or less was considered statistically significant. All calculations and statistical evaluation of results were performed using Excel (2000) and GraphPad Prism version 3.00 for Windows (GraphPad Software, San Diego, Calif., USA). Data are presented as means \pm SD in the text, while figures show means \pm SEM.

\section{Results}

Mixed meal tolerance test. Fasting plasma glucose was significantly increased by reduction of beta cell mass $(4.1 \pm 0.1$ vs $3.3 \pm 0.1 \mathrm{mmol} / \mathrm{l}$ in the same animals before $\mathrm{NIA}+\mathrm{STZ}, p<0.01)$ and showed a tendency towards an increase compared with the control group (Table 2). Fasting plasma insulin was not significantly reduced by reduction of beta cell mass $(15 \pm 7$ vs $24 \pm 5 \mathrm{pmol} / \mathrm{l}$ before NIA+STZ), but was significantly lower than in the
Table 3. Total insulin secretion during perfusion of pancreata from Göttingen minipigs after reduction of beta-cell mass with $\mathrm{NIA}+\mathrm{STZ}$ in comparison to control pancreata

\begin{tabular}{lcc}
\hline Stimulus (mmol/l) & \multicolumn{2}{l}{ Insulin secretion $(\mathrm{pmol})$} \\
\cline { 2 - 3 } & $\begin{array}{l}\text { Control } \\
\text { pancreata } \\
(n=6)\end{array}$ & $\begin{array}{l}\text { NIA+STZ } \\
\text { pancreata } \\
(n=6)\end{array}$ \\
\hline Glucose 3.5 & $77 \pm 132$ & $153 \pm 167$ \\
Glucose 5 & $450 \pm 398$ & $774 \pm 832$ \\
Glucose 10 & $1021 \pm 640$ & $1119 \pm 993$ \\
Glucose 20 & $1219 \pm 622$ & $1295 \pm 992$ \\
Glucose 5 + GLP-1 10a & $2317 \pm 235$ & $1701 \pm 563^{*}$ \\
Glucose 20 + GLP-1 10 & $2503 \pm 170$ & $2193 \pm 518^{\text {a }}$ \\
Glucose 5 + arginine 5 & $665 \pm 183$ & $230 \pm 145^{* *}$ \\
Glucose 20 + arginine 5 & $956 \pm 270$ & $510 \pm 194 * *$ \\
\hline
\end{tabular}

a Concentration in pmol. * $p<0.05, * * p<0.01$ vs control pancreata by repeated measures two-way ANOVA

control group. The AUC for glucose was significantly higher in the NIA+STZ group than in the control group, but the total insulin response was not reduced (Fig. 1). However, the insulin response was delayed in the $\mathrm{NIA}+\mathrm{STZ}$ group, and the total response during the first 30 minutes after the MMTT was reduced in these animals. Since beta cell mass was significantly reduced, the relationship between insulin response during the entire MMTT and beta cell mass (AUC insulin / beta cell mass) was significantly increased in NIA+STZ animals compared with the control animals $(p<0.05)$ (Fig. 2).

Fasting plasma glucose was measured every 1 to 2 weeks in the NIA+STZ animals and did not change significantly from the MMTT (performed 1 week after NIA+STZ dosing) to the time of isolation and perfusion of the pancreas (range $3.0-4.9 \mathrm{mmol} / \mathrm{l}$ for all measurements).

Pancreas morphology and beta cell mass. Beta cell mass was significantly reduced in the NIA+STZ group compared with the control group $(p<0.01)$ (Fig. 2), whereas the non-beta cell endocrine cell mass was not significantly different $(153 \pm 33$ vs $184 \pm 30 \mathrm{mg}$ in control animals, NS).

Islet morphology was not as compact as in mice or rats but - as previously reported - rather loose, with a noticeable specific loss of beta cells in the NIA+STZ group [19, 27]. 


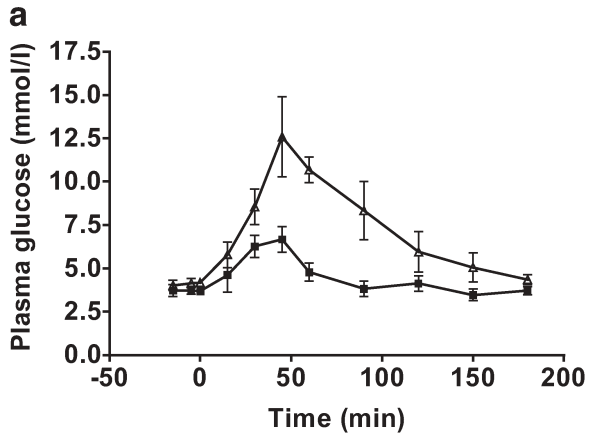

Fig. 1. Plasma glucose (a) and insulin (b) in Göttingen minipigs during MMTT in control (black squares, $n=6$ ) and NIA+STZ animals (black triangles, $n=6$ ). Data are shown as means \pm SEM

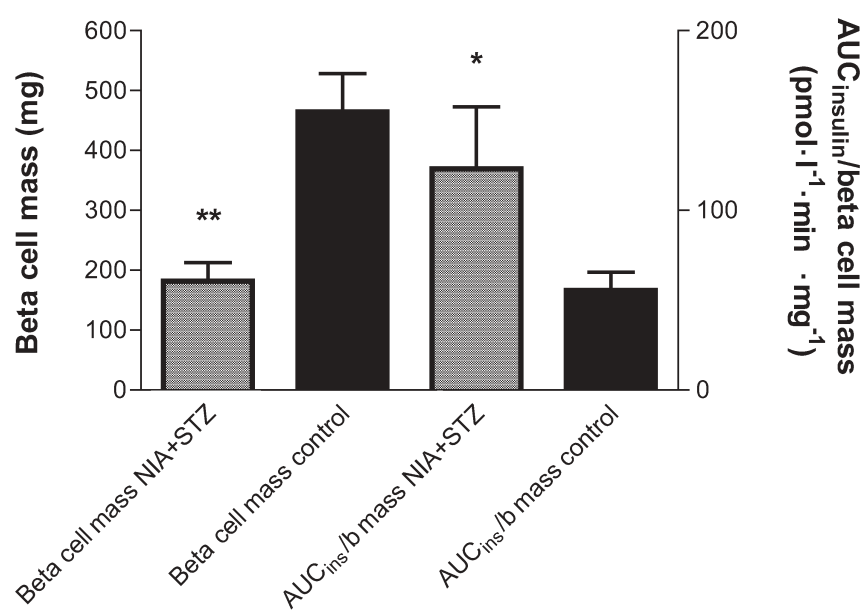

Fig. 2. Beta cell mass (left) and insulin response during MMTT relative to beta cell mass $\left(\mathrm{AUC}_{\mathrm{ins}} / \mathrm{b}\right.$ mass, right) in control (black bars, $n=6$ ) and NIA+STZ Göttingen minipigs (grey bars, $n=6$ ). Data are shown as means \pm SEM. ${ }^{* *} p<0.01$, $* p<0.05$ vs control animals

Perfused pancreas. Total insulin secretion in response to glucose did not differ between the two groups (Table 3), whereas total insulin secretion in response to either GLP-1 or arginine was significantly lower in the NIA+STZ group.

However, pancreata from NIA+STZ animals secreted more insulin per unit beta cell mass than those from control minipigs $(83.7 \pm 45.9$ vs $34.6 \pm$ $14.4 \mathrm{nmol} / \mathrm{mg}$ beta cells, $p<0.05$ ) (Fig. 3), and this response correlated with the in vivo observations in the individual animals $\left(r^{2}=0.55, p<0.01\right)$. Similarly, insulin secretion in response to increasing concentrations of glucose relative to beta cell mass tended to be increased in the NIA + STZ pancreata $(p=0.1$, Fig. 3), and was significantly increased in response to GLP-1 $(p<0.05)$. However, the in vitro insulin response to arginine relative to beta cell mass was similar in the two groups.

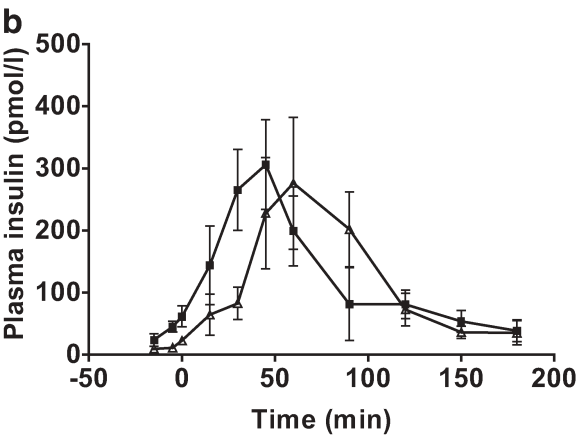

\section{Discussion}

In agreement with previous reports, a reduction in beta cell mass of around $70 \%$ resulted in mild fasting hyperglycaemia and post-prandial hyperglycaemia in the present study $[19,20]$. The in vivo insulin secretory response to an MMTT after NIA+STZ was delayed rather than reduced, indicating that the remaining beta cells compensate for the reduced mass by secreting more insulin during a physiological stimulus. However, when applying more extensive stimulation with a combination of glucose and arginine, the insulin response in this model has been shown to be clearly related to beta cell mass [20]. This difference could indicate that, during more extensive stimulation of insulin secretion (such as intravenous glucose plus arginine), beta cells in NIA+STZ animals are not able to compensate for the reduced beta cell mass.

This interpretation is further supported by the partial compensation seen after stimulation with GLP-1 and the lack of compensation in response to arginine stimulation in vitro. In line with the results of the in vivo experiments in this study, glucose-stimulated insulin secretion was not reduced in perfused pancreata from NIA+STZ animals, whereas a reduction was seen in response to both GLP-1 and arginine. This indicates that the remaining beta cells were only partially able to compensate in the isolated organ. Similarly, in the perfused pancreas from rats dosed with NIA+STZ [28], insulin responses to glucose, tolbutamide and arginine indicate that secretory responses are related to pancreatic insulin content but, as in the present study, some compensation for the reduced beta cell mass seems to occur.

The results from the perfused pancreas in the present study demonstrate that reduced beta cell mass is more efficiently compensated for in response to glucose than GLP-1, and is not compensated for in response to arginine stimulation. This suggests that not only the magnitude of the stimulus, but also the different mechanisms leading to insulin secretion affect the ability to compensate in this model.

The delayed insulin response to glucose seen in vivo may, to some extent, be mediated by neuronal mechanisms working in combination with the reduced beta cell mass after NIA+STZ dosing. In STZ diabetic rats, it has been reported that the stimulation of insulin 


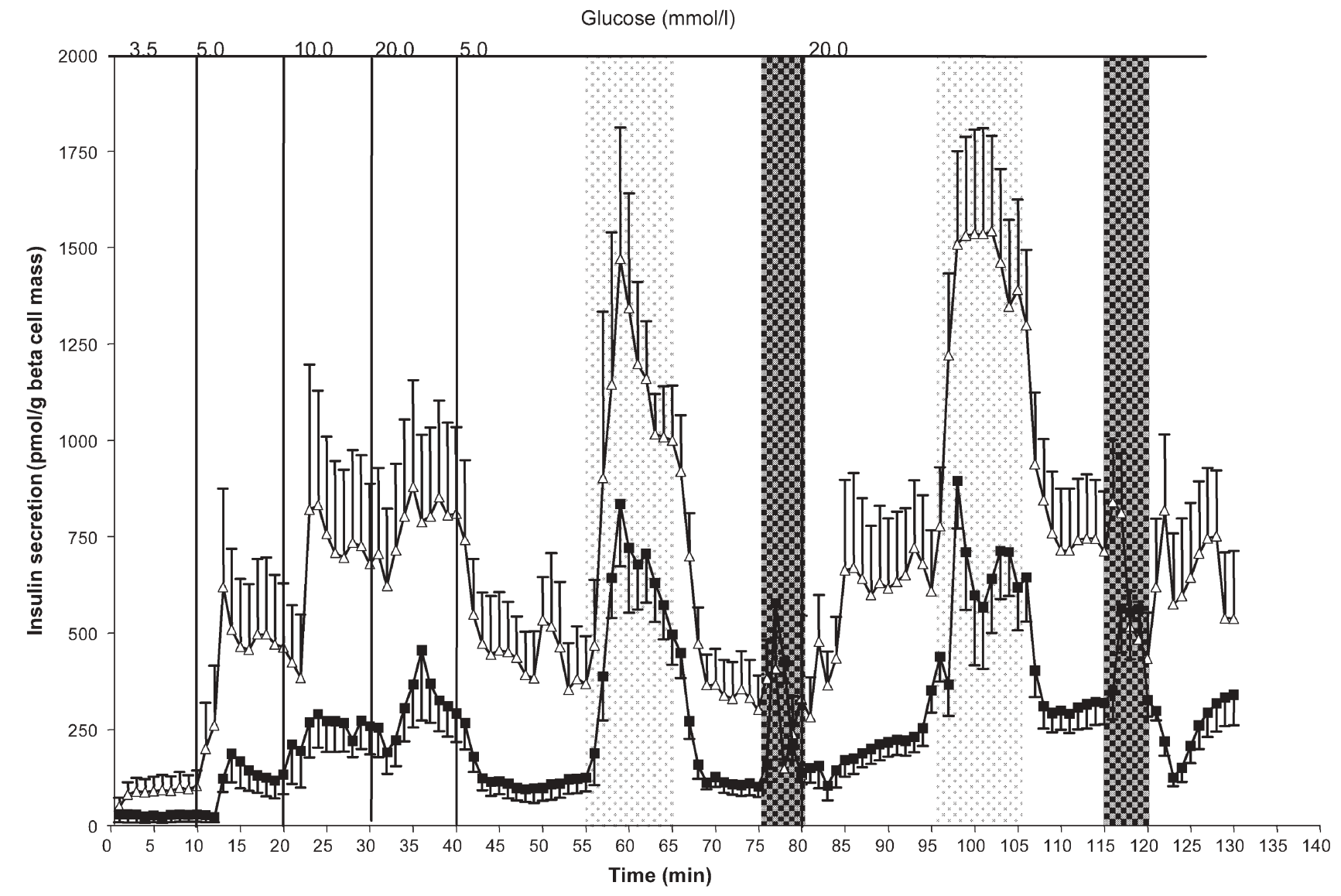

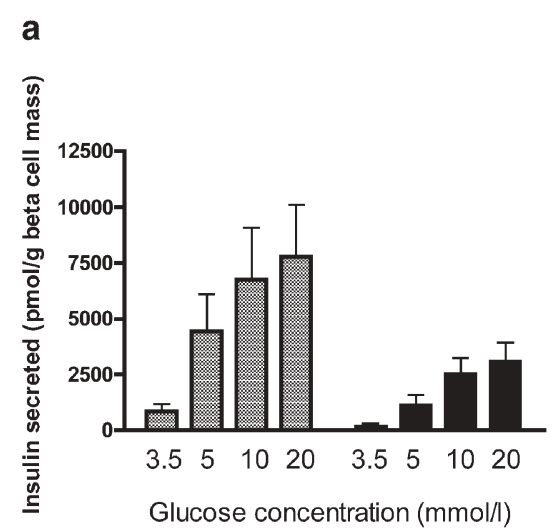

Fig. 3. The upper panel shows a graph of insulin secreted per gram of beta cell mass during perfusion of isolated pancreas from control (black boxes, $n=6$ ) and NIA+STZ Göttingen minipigs (open triangles, $n=6$ ). Glucose concentrations in the perfusion media are indicated at the top of the panel. Lightly hatched areas indicate GLP-1 $(10 \mathrm{nmol} / \mathrm{l})$ in the perfusion medium, whereas dark hatched areas indicate arginine $(5 \mathrm{mmol} / \mathrm{l})$. The lower panels shows graphs of total insulin secreted per gram of beta cell mass by isolated perfused pancreata from control (black bars, $n=6$ ) and NIA+STZ Göttingen minipigs (hatched bars, $n=6$ ). a. Response to stimulation with increasing concentrations of glucose in the perfusion medium. b. Response to GLP-1 $(10 \mathrm{nmol} / \mathrm{l})$ at low and high glucose. c. Response to arginine $(5 \mathrm{mmol} / \mathrm{l})$ at low and high glucose. Data are means \pm SEM. $* p<0.05$ vs control animals

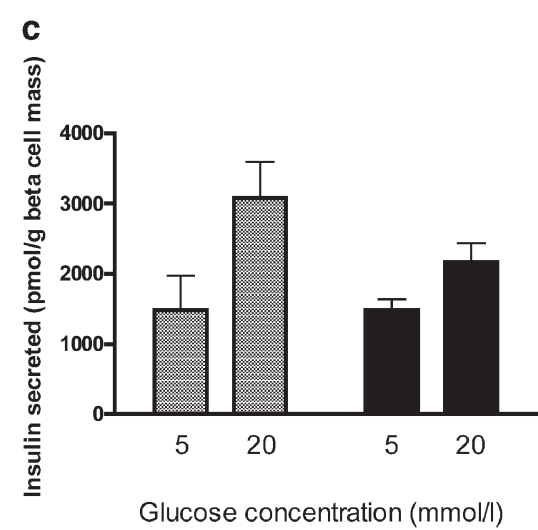

secretion by both vasoactive intestinal polypeptide and substance $P$ was reduced [29]. This could perhaps also be the case in the pigs, and may partly explain why the delayed insulin response seen during MMTT did not occur in the perfused pancreas, where vagal influence is not present.

In conclusion, a primary reduction in beta cell mass of around $70 \%$ impairs glucose tolerance and leads to a compensatory increased insulin response to an MMTT from the remaining beta cell population. This indicates that these cells increase their individual insulin secretion to regulate glycaemia in vivo in the Göttingen minipig. This increased insulin secretion is also seen in the isolated perfused pancreata from the same animals in response to glucose and (to some extent) 
GLP-1, but not arginine. Observations for up to 2 months have shown the stability of this model [19], but whether the remaining beta cells are able to maintain the increased insulin secretion to prevent deterioration of glycemic control in the long term remains to be determined.

However, since the remaining beta cells were largely able to compensate for the reduced beta cell mass both in vivo and in vitro, this study clearly indicates that factors other than a reduced beta cell mass are involved in the beta cell dysfunction seen in type 2 diabetes.

Acknowledgements. We thank H. Nygaard, L. Sejersen Winther, L. Gotlieb Sørensen, A. Grethe Juul, A. Petersen, L. Klarskov, M.V. Olesen, L. Hansen, S. Primdal, S. Kryger, K. Larsen, E. Ebbesen and H. Rasmussen for excellent technical assistance. C. F. Deacon is greatly acknowledged for helpful comments made during the preparation of the manuscript.

\section{References}

1. Leahy JL (1996) Impaired beta-cell function with chronic hyperglycemia: 'Overworked beta-cell' hypothesis. Diabetes Rev 4:298-319

2. Grill V, Björklund A (2001) Overstimulation and beta-cell function. Diabetes 50 [Suppl 1]:S122-S124

3. Vague P, Moulin JP (1982) The defective glucose sensitivity of the B cell in non insulin dependent diabetes. Improvement after twenty hours of normoglycaemia. Metab Clin Exp 31:139-142

4. Garvey WT, Olefsky JM, Griffin J, Hamman RF, Kolterman OG (1985) The effect of insulin treatment on insulin secretion and insulin action in type II diabetes mellitus. Diabetes 34:222-234

5. Glaser B, Leibovich G, Nesher R, Hartling S, Binder C, Cerasi E (1988) Improved beta-cell function after intensive insulin treatment in severe non-insulin-dependent diabetes. Acta Endocrinol 118:365-373

6. Karlsson FA, Bjork E (1997) Beta-cell rest-a strategy for the prevention of autoimmune diabetes. Autoimmunity 26:117-122

7. Laedtke T, Kjems L, Porksen N et al. (2000) Overnight inhibition of insulin secretion restores pulsatility and proinsulin/insulin ratio in type 2 diabetes. Am J Physiol Endocrinol Metab 279:E520-E528

8. Diani AR, Sawada G, Wyse B, Murray FT, Khan M (2004) Pioglitazone preserves pancreatic islet structure and insulin secretory function in three murine models of type 2 diabetes. Am J Physiol Endocrinol Metab 286:E116-E122

9. Skak K, Gotfredsen CF, Lundsgaard D, Hansen JB, Sturis J, Markholst H (2004) Improved beta-cell survival and reduced insulitis in a type 1 diabetic rat model after treatment with a beta-cell-selective KATP channel opener. Diabetes 53:1089-1095

10. Maclean N, Ogilvie RF (1955) Quantitative estimation of the pancreatic islet tissue in diabetic subjects. Diabetes 4:367-376

11. Saito K, Yaginuma N, Takahashi T (1979) Differential volumetry of A, B and D cells in the pancreatic islets of diabetic and nondiabetic subjects. Tohoku J Exp Med 129:273-283

12. Klöppel,G, Öhr M, Habich K, Oberholzer M, Heitz PU (1985) Islet pathology and the pathogenesis of type 1 and type 2 diabetes mellitus revisited. Surv Synth Pathol Res 4:110-125

13. Weir GC, Leahy JL, Bonner-Weir S (1986) Experimental reduction of B-cell mass: implications for the pathogenesis of diabetes. Diabetes Metab Rev 2:125-161

14. Clark A, Wells CA, Buley ID et al. (1988) Islet amyloid, increased A-cells, reduced B-cells and exocrine fibrosis: quantitative changes in the pancreas in type 2 diabetes. Diabetes Res 9:151-159

15. Butler AE, Janson J, Bonner-Weir S, Ritzel R, Rizza RA, Butler PC (2003) Beta-cell deficit and increased beta-cell apoptosis in humans with type 2 diabetes. Diabetes 52:102-110

16. Leahy JL, Bonner-Weir S, Weir GC (1988) Minimal chronic hyperglycemia is a critical determinant of impaired insulin secretion after an incomplete pancreatectomy J Clin Invest 81:1407-1414

17. Portha B, Srradas P, Bailbe D, Suzuki K, Goto Y, Giroix M (1991) Beta-cell insensitivity to glucose in the GK rat-a spontaneous nonobese model for type II diabetes. Diabetes 40:486-491

18. Lee HC, Bonner-Weir S, Weir GC, Leahy JL (1989) Compensatory adaption to partial pancreatectomy in the rat. Endocrinology 124:1571-1575

19. Larsen MO, Wilken M, Gotfredsen CF, Carr RD, Svendsen O, Rolin B (2002) Mild streptozotocin diabetes in the Gottingen minipig. A novel model of moderate insulin deficiency and diabetes. Am J Physiol Endocrinol Metab 282:E1342-E1351

20. Larsen MO, Rolin B, Wilken M, Carr RD, Gotfredsen CF (2003) Measurements of insulin secretory capacity and glucose tolerance to predict pancreatic beta-cell mass in vivo in the nicotinamide/streptozotocin Göttingen minipig, a model of moderate insulin deficiency and diabetes. Diabetes 52:118-123

21. Jensen SL, Kühl C, Nielsen OV, Holst JJ (1976) Isolation and perfusion of the porcine pancreas. Scand J Gastroenterol Suppl 37:57-61

22. Jensen SL, Fahrenkrug J, Holst JJ, Kühl C, Nielsen OV, Schaffalitzky de Muckadell OB (1978) Secretory effects of secretin on isolated perfused porcine pancreas. Am J Physiol 235:E381-E386

23. Holst JJ, Ostenson CG, Harling H, Messell T (1990) Porcine pancreastatin has no effect on endocrine secretion from the pig pancreas. Diabetologia 33:403-406

24. Andersen L, Dinesen B, Jørgensen PN, Poulsen F, Røder ME (1993) Enzyme immunoassay for intact human insulin in serum or plasma. Clin Chem 39:578-582

25. Bock T, Svenstrup K, Pakkenberg B, Buschard K (1999) Unbiased estimation of total beta-cell number and mean beta-cell volume in rodent pancreas. APMIS 107:791-799

26. Gundersen HJG (2002) The smooth fractionator. J Microsc 207:191-210

27. Larsen MO, Gotfredsen CF, Wilken M, Carr RD, Porksen N, Rolin B (2003) Loss of beta-cell mass leads to a reduction of pulse mass with normal periodicity, regularity and entrainment of pulsatile insulin secretion in Göttingen minipigs. Diabetologia 46:195-202

28. Masiello P, Broca C, Gross R et al. (1998) Experimental NIDDM: development of a new model in adult rats administered streptozotocin and nicotinamide. Diabetes 47:224229

29. Adeghate E, Ponery AS, Pallot DJ, Singh J (2001) Distribution of vasoactive intestinal polypeptide, neuropeptide-Y and substance $\mathrm{P}$ and their effects on insulin secretion from the in vitro pancreas of normal and diabetic rats. Peptides 22:99-107 